\title{
Knowing Russia's Convicts: The Other in Narratives of Imprisonment and Exile of the Late Imperial Era
}

\author{
SARAH J. YOUNG
}

\begin{abstract}
The essay explores the significance of questions of knowledge to the depiction of prisoners in three prominent katorga narratives from the second half of the nineteenth century: Dostoevskii's Notes from the House of the Dead, Kennan's Siberia and the Exile System, and Chekhov's Sakhalin Island. Comparing the different discourses of unknowability these authors employ, it argues that the relationship of the writers or narrators to the outcast status of the convicts takes their texts beyond the immediate context, to shape views of the penal system as expressing the increasing instability of identity, social hierarchies and moral life in Russia.
\end{abstract}

STUDIES OF THE EXILE AND PRISON POPULATIONS OF SIBERIA IN the Imperial era have, until recently, privileged the experiences of the relatively small number of representatives from the educated and articulate elite, and of political prisoners, over the majority convicted of criminal offences, who came mainly from the peasantry. As Lincoln (1994, p. 175) states, 'history remembers little about this horde', whose 'faces do not readily emerge', and our understanding of this more common experience of punishment remains underdeveloped. Current attempts to uncover the traces left by ordinary prisoners, thereby providing a fuller picture of the experience of imprisonment and exile, are reflected in the present collection by Sarah Badcock's contribution, in which she addresses the problem of the unknown and unknowable 'punished' by examining the question of illness, an area where the voices of the doubly marginalised may be heard. This essay seeks to complement her approach by exploring depictions of, and relationships with, ordinary convicts in three texts that have made significant contributions to the popular image of Siberia and debates about Russian

The initial stage of my research project on Russian labour camp narratives was funded by a Leverhulme Special Research Fellowship at the Department of Russian and Slavonic Studies, University of Nottingham. I acknowledge the support of the Leverhulme Trust with thanks. I would like to thank the editors of this special issue of Europe-Asia Studies, participants in the 'Villains and Victims' conference, University of Nottingham, April 2010, and panellists and audience at the BASEES annual conference, Cambridge, March 2010 , for the discussion and comments about aspects of my essay, which proved very helpful in the process of revision. I am also grateful to the two anonymous reviewers for Europe-Asia Studies for their positive and useful comments.

ISSN 0966-8136 print; ISSN 1465-3427 online/13/901700-16 @ 2013 The Author(s). Published by Taylor \& Francis. This is an Open Access article distributed under the terms of the Creative Commons Attribution License (http:// creativecommons.org/licenses/by/3.0), which permits unrestricted use, distribution, and reproduction in any medium, provided the original work is properly cited. The moral rights of the named author(s) have been asserted.

http://dx.doi.org/10.1080/09668136.2013.844509 
penal policy, in both Russia and abroad, in order to conceptualise the framework in which the convicts' unknowability is constructed.

In addressing the unknowability of convicts and the role this plays in Siberian texts, Anton Chekhov's Ostrov Sakhalin, published in 1895, is crucial, ${ }^{1}$ because of the author's initial aim of understanding the island's population by conducting a census; his text catalogues the inadequacy of his approach, as he proves unable to gather the information he requires (Chekhov 1978, pp. 66-75). Popkin (1992, p. 39), noting that 'these convicts are not accessible to [Chekhov] as real objects of knowledge', has described this feature of Sakhalin Island as evidence of an epistemological crisis which renders inapplicable the ideal of total surveillance and complete knowledge that underpins power in the panoptic paradigm of Foucault's analysis of the European penal system: '[t]he complete failure to distinguish between prisoners makes impossible any Foucauldian quantification or scientific calibration of sentence to crime' (p. 44). Popkin (1992, p. 51) avers that the failure of knowledge is central to the 'senselessness and horror' Chekhov conveys, and suggests that the anti-panoptic model he depicts originates in aspects of the exile system itself (p. 49); however, her article does not elaborate on the latter point.

Examination of Sakhalin Island alongside two other famous texts which Chekhov knew before his own visit (Chekhov 1978, pp. 60,320) and to which his own work was in part a response-Dostoevskii's Zapiski iz mertvogo doma, published in $1861^{2}$ and George Kennan's two volumes of Siberia and the Exile System (1891) ${ }^{3}$-reveals that Chekhov was not alone in experiencing the failure of knowledge, suggesting a broader underlying question than that of the inadequacy of his scientific approach. ${ }^{4}$ These texts merit comparison because they reflect three paradigmatic outsider positions in relation to the subject matter: the prisoner, the Russian visitor and the overseas visitor, each separated from-and therefore lacking knowledge of - the peasant convicts to a different degree. In addition to covering substantially different ground by virtue of their authorial perspectives, the works also represent different but overlapping genres that frame the topic in different ways and encompass both factual and fiction forms, conforming to a tendency 'towards generic hybridization' (Cole 1991, p. 93) apparent in Russian prison writing. Kennan's generally straightforward travelogue is complemented by Chekhov's use of the modes of travel notes and scientific and sociological research, as well as his incorporation of more literary features (Ryfa 1999, pp. 69-70), whilst Dostoevskii's work hovers unstably between memoir, sketches, fiction (Dwyer 2012, p. 210) and documentary prose (Jackson 1981, p. 6). Each text, moreover, contains polemical features that mark significant moments in the development of writing about Siberian katorga: Dostoevskii's novel is frequently cited as the foundational text for the tradition of Russian prison writing; Chekhov's work led to a significant debate within Russia about the penal system and instigated some reform (Ryfa 1999, p. 211); and Kennan's volumes provide the international dimension that became increasingly important in discussions of the 'Siberian question', and the forms and places of

\footnotetext{
${ }^{1}$ For a translation into English see Chekhov (2007).

${ }^{2}$ For a translation into English see Dostoevsky (2004).

${ }^{3}$ On connections between Notes from the House of the Dead and Sakhalin Island, see Cole (1991, pp. 111-19), Ryfa (1999, pp. 143-74) and Polakiewicz (2001). Ryfa (1999, pp. 120-23) also discusses the relationship between Kennan's Siberia and the Exile System and Chekhov's Sakhalin Island.

${ }^{4}$ A similar pattern is also apparent in Doroshevich (1903), but this work is excluded from consideration as, written only a few years after Chekhov's, about the same places, institutions and, in some cases, people, it covers much of the same ground as its predecessor, particularly in relation to the question of knowledge.
} 
punishment in Russia in the late nineteenth century through the campaigns of émigré groups and others (Hollingsworth 1970, pp. 50, 52, 55).

By covering these different dimensions through the three works, the present essay seeks to expand Popkin's approach and establish its wider applicability to discussions of Siberia and katorga during the late Imperial era. It explores the ways in which the problem of knowledge, emerging in the texts on the linguistic and thematic levels, and the estrangement of both authors and prisoners, become the bases within all three works for consideration of the social and moral effects of imprisonment, transcending the generic differences they represent, as the inability to know the convicts comes to reflect a wider problem in Russian society.

\section{Siberia and the Exile System}

George Kennan's record of his travels in 1885 is, like Chekhov's text, full of facts and figures. He emphasises from the beginning that the primary reason for his visit is 'the acquirement of knowledge' (Kennan 1891a, p. 27), and characterises himself and his companion Mr Frost as initially ignorant-in Perm, they pass the prison a number of times because they 'did not know any better', causing them trouble with the local authorities (p. 25)—but quickly overcoming such problems. Kennan's language represents the acquisition of knowledge as a largely straightforward process; of the 503 occasions on which he uses different forms of 'knowing' words in the two volumes, only 78 are negated, with 48 admitting to a lack of knowledge on the part of the author, while the word 'unknown', denoting inaccessible knowledge, is used only 15 times. $^{5}$

Although they concur in condemning many of the iniquities of imprisonment, Kennan presents his experience of gaining insight into the Siberian question as different to Chekhov's, initially supporting Popkin's (1992, p. 50) contrast of the Russian's problematising of knowledge with the American's ease in obtaining it. However, examination of Kennan's apparently more authoritative approach and ready access to information reveals gaps in his knowledge, pertaining specifically to the subject of prisons and their inhabitants. On the former question, the statistics to which he refers for the most part have nothing to do with prison and exile, but are rather general population, industrial production and geographical figures (Kennan 1891a, p. 157). The major exception to this rule - the four tables giving details of illnesses and death-rates at the Tyumen forwarding prison (pp. 96-99)—contain, according to Kennan's footnotes, four errors, one of which he fails to resolve, and may therefore be viewed with at least a degree of scepticism.

The gap concerning the prisoners themselves is more revealing, as within Kennan's text the ordinary prisoners are effaced to the point of disappearance, represented as an undistinguished mass or transformed into shadows. In his descriptions of prison cells, the inhabitants seem to feature only insofar as they illustrate the conditions:

The Cossack corporal who preceded us threw open the heavy wooden door of the first kámera [cell] and shouted, 'Smirno!' [Be quiet!] the customary warning of the guard to the prisoners when an

\footnotetext{
${ }^{5}$ All word frequency analyses were conducted using the concordance software TextSTAT $2.8 \mathrm{~g}$, http:// neon.niederlandistik.fu-berlin.de/en/textstat/, accessed 20 July 2010. For further details on the process of constructing and using concordances for literary analysis, see Young (2010). My thanks to John Levin for his technical assistance with installing and using the concordance application.
} 
officer is about to enter the cell. We stepped across the threshold into a room about 24 feet long, 22 feet wide, and 8 feet high, which contained 29 convicts. The air here was so much worse than the air in the corridor that it made me faint and sick. The room was lighted by two nearly square, heavily grated windows with double sashes, that could not be raised or opened, and there was not the least apparent provision anywhere for ventilation. Even the brick oven, by which the cell was warmed, drew its air from the corridor. The walls of the kámera were of squared logs and had once been whitewashed; but they had become dark and grimy from lapse of time, and were blotched in hundreds of places with dull red blood-stains where the convicts had crushed bedbugs; the floor was made of heavy planks, and, although it had recently been swept, it was incrusted with dry, hardtrodden filth. Out from the walls on three sides of the room projected low, sloping wooden platforms about six feet wide, upon which the convicts slept, side by side, in closely packed rows, with their heads to the walls and their feet extended towards the middle of the cell. They had neither pillows nor blankets, and were compelled to lie down upon these sleeping-benches at night without removing their clothing, and without other covering than their coarse gray overcoats. The cell contained no furniture of any kind except these sleeping-platforms, the brick oven, and a large wooden tub. When the door was locked for the night each one of these 29 prisoners would have, for 8 or 10 hours' consumption, about as much air as would be contained in a packing-box 5 feet square and 5 feet high. If there was any way in which a single cubic foot of fresh air could get into that cell after the doors had been closed for the night I failed to discover it.

We remained in the first kámera only two or three minutes. (Kennan 1891b, pp. 146-47) ${ }^{6}$

The 29 convicts here are almost invisible, their physical presence evinced mainly by the spatters of blood left by the crushed bedbugs that testify to the violence of prison life. ${ }^{7}$ By focusing on the conditions in this way, Kennan's approach emphasises that the dehumanisation of the prisoners has brought them to the point of non-existence, their identities completely erased.

This sense of the convicts' effacement is apparent in closer encounters with individuals, which do not impart any greater sense of identity. When the visitors study the faces of the prisoners, and Frost draws pictures of 'convict types' (Kennan 1891a, pp. 118-19), they are chosen for their typicality, highlighting the absence of individuality and suggesting that the only means of knowing them is through their resemblance to each other. Over the two volumes, Kennan records only two brief dialogues between himself and convicts. The first, with a Latvian brodyaga (vagrant) of English descent called John Anderson, is conducted in English (pp. 372-73); Kennan speaks Russian, but the first convict to be endowed with personality or agency speaks his own native tongue, and therefore resembles the author. On the following page, the second encounter he reports is with a man of 'intelligence and education' (p. 374), who also engenders a fleeting sense of familiarity with his questions about the Americans' photographic equipment, but Kennan is drawn away before any real engagement can arise, and this convict is unnamed, distanced and unindividualised; even educated prisoners, it seems, have little chance of maintaining an identity.

Similar effects of distancing are apparent in other contexts. Emphasis is placed on habitual aspects of the convicts' existence, with frequentative descriptions (Kennan 1891b, pp. 159-60), which allow consideration of their plight and the conditions in which they live,

\footnotetext{
157)

${ }^{6}$ Similar depopulation is apparent in other descriptions of the cells at Kara; see Kennan (1891b, pp. 149,

${ }^{7}$ My thanks to Julia Chadaga for pointing out to me the allusion in the bedbugs' blood to the violence of both the prisoners themselves and their lives in the prison.
} 
whilst preventing them emerging as individuals. Likewise, in the anecdotes told by officials, not only are the convicts deprived of their own voice, but the form the stories take remove them to the generic realm. When one prison official tells Kennan, 'I once had a convict servant ... who was one of these irreclaimable vagrants' (p. 154), the emphasis again is on the type rather than the person. But by positioning a portrait of an 'old hard-labor convict' on the following page to illustrate the type, Kennan implies this is the individual to whom the story refers, and thereby gives this unnamed prisoner a face, whilst still alluding to his only possible status as representative. The use of sketches throughout, despite references to photographic equipment (Kennan 1891a, pp. 5, 114), implies a further level of distancing, as rather than documenting specific people, sketches may be viewed as works of the imagination or as amalgamating different features of multiple subjects in a single drawing, thereby subverting any sense of individuality the portraits may suggest.

A comparison with the other potentially estranging groups Kennan encounters underlines the significance of his portrayal, or to be more precise, his non-portrayal, of ordinary convicts. His mental image of political exiles as crazed, alien beings dissipates immediately upon meeting them (Kennan 1891a, p. 174), and he then proceeds, unlike with the two brodyagi he encounters, to give extended, sympathetic descriptions of individuals, their cases and the time he spends with them (Kennan 1891a, pp. 160-87; 1891b, pp. 166-277). In his accounts of the native Kirghiz and Buryat tribes (Kennan 1891a, pp. 140-67; 1891b, pp. 60-97), a desire to portray the exotic aspects of Siberian life is evident, but even as differences in language and culture are emphasised, they are erased through the mediation of 'Khainuief's unrivaled skill as a translator of truth into fiction' (Kennan 1891b, p. 92). This apparently one-way process-Kennan does not question whether the translator is also adapting information for American ears-in which the visitors are presented according to Buryat and Russian cultural norms, draws them closer to their hosts whilst highlighting the exoticism of the latter.

The play of familiarisation and estrangement in this scene is part of a wider trope of comparison and contrast in Kennan's work. At the beginning of his journey, he frequently highlights the similarities between the Russian landscape and those of Europe and America:

The scenery of the Urál where the railroad crosses the range resembles in general outline that of West Virginia where the Baltimore and Ohio railroad crosses the Alleghanies ... [the train] sometimes coming out into beautiful park-like openings diversified with graceful clumps of silver birch, and carpeted with turf almost as smooth and green as that of an English lawn. (Kennan 1891a, p. 32)

As he travels deeper into Siberia, however, such comparisons disappear, and instead the difference represented by Russian practices is stressed: 'Deportation by étape in Siberia is attended by miseries and humiliations of which a European or American reader can only form a faint conception' (Kennan 1891a, p. 397). The sense of estrangement Siberia engenders in those who travel to it-both voluntary visitors and involuntary convictsoriginates not primarily in its geography or its native inhabitants, therefore, but in the prison and exile system introduced by European Russia, the major victims of this being the convicts who populate it. It is they, rather than the colonised natives, who emerge as Siberia's shadowy other; distanced, homogenised and hidden from view, neither familiar nor exotic, the inaccessibility of the convicts forms a lacuna in the text as the author persistently alludes to his inability to speak of them. 
The aim of Kennan's book, as the title suggests, is to explicate the system of Siberian exile, and this he does with great aplomb. Framing Siberia as a penal problem, he implies that its otherness originates not in its exotic unfamiliarity or remoteness, but in Russia's governance. He became famous in the years following his visit and publication of his Siberian text for campaigning against the evils perpetrated by the Russian autocracy (Hundley 2000), and his portrayal of the marginalisation and dehumanisation of the convicts is shaped primarily to contribute to an understanding of the wrongs of the system, and support the political case he makes. In contrast, both Dostoevskii and Chekhov start from the opposite direction, attempting to place the convict at the centre of their works. In doing so, they are confronted with different problems of not knowing which not only reconfigure the Siberian question in social and moral terms, but also have a radical impact on their own (or their narrator's) identity.

\section{Notes from the House of the Dead}

Goryanchikov, the narrator of Dostoevskii's fictionalised memoir, exhibits a strong desire to know the convicts and, as Murav (1991, p. 862) suggests, approaches his incarceration like a 'visiting anthropologist' or, one might prefer, a novelist. The text is punctuated with references to the narrator's close observations of the prisoners around him, with the word curiosity (lyubopytstvo) and its derivatives appearing 45 times. For example, on entering his new barrack, he notes, 'I would have to live in it for many years, and these men were all my future barrack-mates and companions. It is easy to understand that I stared at them with avid curiosity' (Dostoevskii 1972, p. 50). ${ }^{8}$ When arriving in the prison hospital, he states, 'I examined my new companions with curiosity, but, I recall, there was one man in particular who aroused my curiosity' (p. 134). However, it becomes increasingly apparent that whatever the narrator's efforts, he fails in his quest to know his fellow prisoners. ${ }^{9}$ In the early stages, he asks, 'Who can say that he has fathomed the depths of these lost hearts and read in them what is kept from the whole world?' (p. 15), but this never changes; throughout the novel he remains 'eternally alienated' (Frank 2010, p. 201), only able to describe external appearances and actions, resorting to speculation about their inner lives. ${ }^{10}$ Goryanchikov's language betrays his lack of certainty about the other convicts, with frequent use of the phrases 'as though' (kak budto), which appears 131 times in the novel, and 'must have' (dolzhen/dolzhno and its other forms; 60 occurrences). For example, 'In essence, he could not but despise me, and certainly must have looked upon me as a submissive, weak, pathetic and in every respect beneath him' (Dostoevskii 1972, p. 48) and, 'who knows how many recollections must have stirred in the souls of these outcasts as they greeted such a day! ... These are days of rest from strenuous labour, days of family gatherings. In prison they must have been recalled with anguish and torment' (pp. 104-5).

\footnotetext{
${ }^{8}$ Translations are based on Dostoyevsky (2004), with alterations to emphasise the linguistic points under consideration.

${ }^{9}$ See Ruttenburg (2008, p. 51) on the unbridgeable gulf between Goryanchikov, as a member of the nobility, and the common convicts.

${ }^{10}$ Dwyer (2012, p. 221) connects the inability to know the ethnically Russian convicts to allusions to 'illegible faces' and emphasis on 'bodily surfaces' in the text.
} 
In the face of this failure to penetrate the inner lives of the convicts, the narrator's ability to know in more general terms is placed under question. The use of the verb 'to know' (znat') in Notes from the House of the Dead is significant, in particular in the first person; the I-form is negated 47 times, and only given positively 19 times. The emphasis on notknowing is in no way so marked in other parts of the verb; the third person singular, for example, appears 42 times in the positive, and only three times in the negative. A number of these posit uncertainty about the possessor of knowledge ('who knows' appears 11 times, and 'God knows', six), but the overwhelming sense is that knowledge is available to somebody other than the narrating 'I', or indeed perhaps any 'I'. Most emphatically, knowledge is posited as accessible to the collective, rather than the individual; while there are only seven instances of 'they did not know' in the text, 'they knew' appears 36 times; on 11 of these occasions, the collective nature of knowledge is emphasised by the inclusion of 'all' (vse). A similar pattern is discernible in relation to the vocabulary of understanding (ponyatie) in the novel. Whilst adverbs and adjectives are generally given in positive form, suggesting the possibility of understanding, verbs are overwhelmingly negated; 14 out of 15 instances of the infinitive 'to understand' are negated, and the eight out of 15 occurrences of 'I/he didn't understand' in the text refer either to the narrator misunderstanding, or being misunderstood, also denoting the difficulty of attaining understanding for the individual, particularly the narrator. Again, the collective emerges as the locus of understanding; third person plurals are negated only once. ${ }^{11}$

Dostoevskii's narrator therefore consistently attempts to know the convicts, sketches of whom account for a large proportion of the narrative, but his discourse reveals the impossibility of his task, as the prisoners' knowability is, in practice, restricted to themselves. But this failure is presented not primarily as part of the penal question, but is rather the core of a broader social problem. It is the separation of the élite from the narod that prevents the development of an all-encompassing community in which this knowledge can be shared, even when a member of that élite is apparently brought down to the level of the peasantry and perforce participates in their outsideness. The outsideness Goryanchikov experiences is not due to his position as a convict, but is the result of an insideness-the sealed nature of the peasant or convict community-which is impenetrable to other levels of society. Towards the end of the novel, when Goryanchikov is not permitted by the peasant convicts to support their complaint about the prison food, he admits that the nobleman's separation from the peasants cannot be breached:

No matter how fair, kind, intelligent he is, the other convicts will hate and despise him for years on end; they won't understand him, and most importantly, they won't trust him. He is not their friend and not their comrade, and even if he finally, over the years, may get to the point where they don't insult him, he will still not be one of them and will always be tormentedly conscious of his estrangement and solitude. (Dostoevskii 1972, p. 198)

The prison camp is thus viewed as a space which apparently presents an opportunity for dialogue and understanding between the different classes through the transformation of life into a carnivalised collective (Bakhtin 1984, p. 172), but in fact fixes the otherness of the prisoners - and therefore the peasantry - and confirms their inaccessibility to the outsider.

\footnotetext{
${ }^{11}$ Ruttenburg (2008, p. 62) focuses on different aspects of the invalidation of knowledge in katorga.
} 
As Goryanchikov concludes: 'You may associate with these peasants all your life, you may meet with them every day for forty years, ... you will never get to know their essence' (Dostoevskii 1972, pp. 198-99). ${ }^{12}$

The irreconcilable nature of Goryanchikov's dilemma, and the significance of the position of convict as other in Dostoevskii's novel, are emphasised in the frame narrative when we first meet the narrator, following his release. Here we are presented with a very different Goryanchikov to the curious observer of the prison narrative, as he now pays no attention to his surroundings: 'It turned out that not only did he not know the most ordinary news in our town that was familiar to everybody, but that he was not even interested in knowing it' (Dostoevskii 1972, p. 7). His imprisonment has left him in an untenable position, both belonging to the inaccessible other-his position vis-à-vis the townsfolk parallels his relationship to the convicts (Ruttenburg 2008, p. 70), as indicated in particular by the frame narrator's curiosity about Goryanchikov but inability to know him — and aware of his own inability to know or penetrate that other. His death 'in isolation' (Dostoevskii 1972 , p. 8) denotes a realisation that without this knowledge of the other, he is caught between communities, and this is instrumental in his loss of the will to live. Rosenshield's (1991, p. 322) conception of Notes from the House of the Dead as religious autobiography rests upon the suggestion that Goryanchikov's self-realisation in the novel is dependent on knowledge of the other, and he focuses on the optimism of the end of the novel to show that the narrator has succeeded in gaining this understanding. However, the image of Goryanchikov as a broken man in the introduction, combined with his discourse of notknowing and not-understanding, points to the opposite conclusion: knowing the other is crucial to self-realisation, but Goryanchikov does not achieve either. This, it seems, only becomes apparent in the writing of his memoir, which reveals what he does not and cannot know. ${ }^{13}$

The problem of the other in Notes from the House of the Dead is represented as a part of the larger issue of the separation of the narod and the élite, rather than simply of prisoners and non-prisoners. For this reason, the idea of rehabilitation is implicitly placed under serious question in the novel; the peasant convicts cannot be rehabilitated to rejoin their own society because they never leave it—whilst Goryanchikov is 'eternally alienated', the other prisoners feel at home within two hours of arrival (Dostoevskii 1972, p. 198)—nor can they be rehabilitated to join society proper, because they did not belong to it in the first place. The only function of imprisonment in Dostoevskii's text is to punish and isolate the other of Russian society, but that isolation merely intensifies the division that already exists in Russia and creates an additional level of otherness through its positioning within a colonial context. Beyond the prison, the possibility of the peasants becoming known to the rest of society is denied, because the narod and the convicts are effectively identical. ${ }^{14}$ The other is

\footnotetext{
${ }^{12}$ Frank (2010, p. 203) suggests that Goryanchikov does overcome this barrier and is ultimately able to know the convicts, but the positioning of this incident and these reflections so close to the end of the novel suggests the opposite within the text's symbolic structure.

${ }^{13}$ O'Connor (2010) offers a persuasive interpretation of Goryanchikov's/Dostoevskii's inability to understand his experiences by relating it to the short story 'The Peasant Marei'. My thanks to the author for allowing me access to this unpublished paper.

${ }^{14}$ The story of village life and murder 'Akulka's Husband' (Dostoevskii 1972, pp. 165-73), told by one of the convicts in the prison hospital, which extends the violence of the convicts beyond the prison camp, emphasises the identity between peasant and convict.
} 
viewed therefore not specifically as a problem of Siberia, as is implied by the description in the novel's opening paragraph, ${ }^{15}$ but as one which exemplifies Russian society as a whole.

\section{Sakhalin Island}

For Chekhov, the problem of knowledge shifts this social question into the moral sphere. In his unsuccessful census, he is confronted not only by the failure of scientific methodology, but by a more human question: the loss of memory and the disintegration of identity on the personal level, and of the social collapse that causes. Chekhov's census informs us that it is not only he who is unable to know; the convicts, exiles and settlers to whom he speaks all express a lack of knowledge with regard to themselves (Chekhov 1978, pp. 68-72). Unable to answer questions about their age or how long they have been on the island, they are presented as having a collective mind-set of self-forgetting. While Kennan depicts the practice of giving a false name as a convict ruse-in the conversation cited above, 'Ivan Dontremember' reveals, 'My real name is John Anderson' (Kennan 1891a, p. 293) - Chekhov's description of this phenomenon gives no such indication:

Among vagrants the most commonly used first name was Ivan, and surname Don't-remember [Nepomnyashchii]. Here are a few tramps' nicknames: Mustafa Don't-remember, Vasilii Without a Country [Bezotechestva], Franz Don't-remember, Ivan Don't-remember-aged-20, Yakov NoNickname [Bezprozvaniya], vagrant Ivan-aged-35 [who, as Chekhov's note tells us, is in fact 48], Man-whose-title-no-one-knows [Chelovek Neizvestnogo Zvanya]. (Chekhov 1978, p. 69) ${ }^{16}$

Instead, this practice is presented as a form of non-recollection to be considered alongside other personal confusions on the island, such as that concerning the convicts' and exiles' marital status and eligibility for government allowances (Chekhov 1978, p. 72). It is placed in the context of a broader discourse of indistinguishability. Chekhov (1978, p. 60) discovers that despite the clanking of leg irons, it is frequently impossible to determine convicts from other forms of settler: 'As householders, the convicts in the colony hardly differ at all from the settled-exile householders' (p. 229). ${ }^{17}$ Meanwhile, educated exiles from the privileged classes work in the management of the prison system (p. 159), ${ }^{18}$ and therefore cannot be distinguished from the official appointees who are supposedly guarding them. The impression is created that nobody can know who anybody is, oneself included; it is not only the other who is inaccessible in this colony, as the self also becomes inaccessible upon contact with it.

Just as Dostoevskii's discourse places the possibility of knowing in doubt, Chekhov's language also reflects the problems of knowledge he faces. ${ }^{19}$ He uses the verb 'to know' with remarkable infrequency. In a book of around 110,000 words, the first person singular

\footnotetext{
${ }^{15}$ Bagby (1985) examines the dualised image of Siberia in the opening paragraph of the novel. The difference between the frame narrator's and Goryanchikov's views may explain this discrepancy.

${ }^{16}$ Translations are based on Chekhov (2007), with modifications to highlight the linguistic points under discussion.

${ }^{17}$ This adds another dimension to Imperial concerns about settlers becoming indistinguishable from natives (see Sunderland 1996). Sarah Badcock's use of the term 'the punished' also reflects the difficulty in defining different types of convicts and exiles.

${ }^{18}$ Lincoln (1994, p. 164) also notes this practice.

${ }^{19}$ Cole (1991, pp. 128-30) discusses the parallel problem of the absence of truth on the island.
} 
'I know' appears only 21 times, 15 of which are negated; the third person singular appears in positive form four times, with eight instances of 'he does not know', three of 'who knows' and one of 'the devil knows', while 'they know' appears nine times, of which six are negated. Past tense forms of the verb appear only nine times, and the infinitive ten times, with half negated. Thus if Dostoevskii's work implies that knowledge is elusive but possessed by some, even if that is a group from which his narrator is excluded, Chekhov's suggests so little knowledge is available that the concept is dying out. His negation of the word 'known' (izvestno) further emphasises the sense of unknowability; there are only five instances in the positive form, but 32 in the negative, ${ }^{20}$ in contrast to Dostoevskii, who negates only four out of 66 occurrences of the word. A slightly more mixed picture is presented by the concept of 'understanding' in Chekhov's text. In the abstract, 'understanding' (ponyatie) exists (11 occurrences) and 'understood' appears ten times, but verbal forms, indicating personal understanding, are more frequently negated, again suggesting inaccessibility; in more than half of the appearances of the infinitive, it is 'difficult' (trudno) or 'impossible' (nel'zya) to understand; four out of seven instances of 'they understand' are negated, and in the past tense, both 'I' and 'they' forms are always negated or modified by the adverb 'poorly' (plokho).

Thus, while Dostoevskii's construct privileges the other and posits a 'they' who have knowledge and understanding not accessible to the narrator, emphasising the latter's (and Dostoevskii's) position as doubly outcast, an outsider to both the other convicts and the world at large, Chekhov erases any such divide. He depicts both himself and the other as equally not-knowing and not-understanding; the colony as a whole is cut off and outcast, but all those within it are affected in the same way. There is, for Chekhov, no sense of a collective at work within the colony that has greater resources than those available to the individual. Instead, the isolation of the individual is depicted as having a larger social impact because of the absence of collective cultural memory. Chekhov notes that family life has no sense of the past:

There is no grandfather or grandmother, no old icons or family furniture, so the household lacks a past, lacks tradition. There is no icon-corner, or it is meagre and dim, without icon lamps or decorations - there are no traditional customs; the layout has an incidental character, and it's as if the family is not living in its own home, but in quarters, or as if they have only just arrived and have not yet managed to feel at home; there's no cat, you can't hear crickets on winter evenings ... but the main thing is, there's no feeling of the motherland. (Chekhov 1978, p. 73)

Dreariness, demoralisation and spiritual emptiness are the consequences of such dislocation (Conrad 1985, p. 276), while on a wider scale, attempts to build a peasant society on Sakhalin are undermined:

The rural inhabitants hereabouts have still not formed into a society. There are still no adult nonnatives of Sakhalin, for whom the island would be a motherland, there are very few long-standing residents - the majority are newcomers; the population changes every year; some arrive, others leave; and in some settlements ... the inhabitants create an impression not of rural society, but of a random assembly. They call themselves brothers because they have suffered together, but they have

\footnotetext{
${ }^{20}$ The somewhat more frequent use of the adjective 'izvestnyi' in the positive form suggests that certain individual items of knowledge are available, but that knowledge as a whole is not.
} 
little in common and are strangers to one another. They have different faiths and speak in different languages. (Chekhov 1978, p. 242)

The transience of the population on Sakhalin means that society is unable to take root. Place names do not stick, as in the case of the settlement of Novo-Mikhailovskoe: 'Founded in 1872 and so named because Mitzul's first name was Mikhail. Many writers call it Verkhnii Urochishch, but to the local settlers it is Pashnya' (Chekhov 1978, pp. 116, 203, 206, 208). There is little long-term memory of the land, among either officials or settlers, with the result that inappropriate sites are randomly chosen for settlements or areas are over-settled (pp. 231-37), leading to pointless expenditure of labour or gross overcrowding, both of which encourage settlers and exiles to leave as soon as they can, further undermining social development.

The personal and social amnesia Chekhov describes result in a sense of paralysis and lassitude which seems to infect all forms of life on the island, as indicated by the recurring use of the word 'vyalyi' (sluggish, inert): convicts arriving are 'sluggish and gloomy'; children are 'pale, skinny, inert'; the native Gilyaks' movements are characterised by 'sluggishness and laziness'; even dogs are 'sluggish, not malicious', and the course of epidemics is 'prolonged, but sluggish' (Chekhov 1978, pp. 55, 272, 174, 73, 358). The island appears to have the same effect on all those who come into contact with it; the Japanese are described as normally 'smart, lively and resourceful people', who in relation to their claims on Sakhalin, in contrast, 'behaved somehow in an indecisive and sluggish manner' (p. 223). Chekhov (1978, p. 291) also notes that exiles, even those with trades, sit around with nothing to do. Eventually, this atmosphere affects the author as well, as we see him change from the industrious figure conducting his census in the opening chapters, to his later admission: 'I had grown either tired or lazy, and in the south certainly didn't work as hard as in the north. Often I spent whole days on outings or picnics and no longer had any desire to go round the huts' (p. 198). The failure to obtain knowledge is gradually replaced by a feeling that such efforts are pointless, and as this happens, the author, through his participation in social activities, ceases to be an outsider, as the colony's ability to extinguish difference exerts itself on him as well.

The moral impact of the penal colony on life on the island is apparent not so much in depictions of corruption, known to be rife, ${ }^{21}$ although reference to the obtuseness and dishonesty of every type of petty official ... at every step you have to endure insolence, injustice and the abuse of power' (Chekhov 1978, p. 139) shows the author's awareness of such problems. Rather, the moral question is exemplified in the depiction of punishment itself. This is seen as a negative not only for the prisoners who suffer it directly-their poor treatment is viewed as inevitably corrupting rather than rehabilitating (p. 91)—but also for the rest of the population, for whom the very presence of a penal system jeopardises moral life. Native inhabitants are particularly in danger: 'That proximity to a prison will not Russify, but only completely corrupt, the Gilyaks, there is no need to prove' (p. 179). ${ }^{22}$ Officials and settlers who make use of convict labour for personal gain are guilty of turning reform into slavery (p. 98), while women and children on the island are corrupted wholesale,

\footnotetext{
${ }^{21}$ See, for example, Gentes (2008, p. 84) on the 'embezzlers, extortionists, enslavers and other crooks with official titles who ran Siberia', and Lincoln (1994, p. 83) on the 'raw avarice' of officials in Siberia.

${ }^{22}$ On the question of Russification in imperial Russia, see Sunderland (1996).
} 
the absence of other sources of income forcing the majority of female settlers and exiles to turn to prostitution from a young age (pp. 224-58).

Worst of all, corporal punishment not only 'disgrace[s] the criminal's sense of personal identity and cause[s] physical pain and torment' (Chekhov 1978, p. 332), ${ }^{23}$ but degrades all who participate in it:

Not only do the convicts become coarsened and brutalised from corporal punishment, but so do those who carry out and are present at the punishments. Even educated people are no exception. At least I did not notice officials with a university education behaving any differently towards floggings than army medical assistants or those who had completed courses at military academies or theological seminaries. Some grow so used to lashings and birchings and become so callous that finally they begin to find pleasure in tearing flesh. (Chekhov 1978, p. 338)

As in the case of Dostoevskii, who uses descriptions of floggings to develop the theme of the violence of Russian society and the 'executioner within' (Ruttenburg 2008, pp. 47-49), Chekhov also shows that violence and enjoyment of violence infect all levels of society. As Jackson (1993, p. 79) notes, in the context of Chekhov's understated description, his revulsion at the scene is apparent in his need to turn away. But if Goryanchikov's assertion that 'the qualities of the executioner are present in embryonic form in almost every modern person' (Dostoevskii 1972, p. 155) implicitly includes himself, Chekhov's action attempts to distance himself from the moral disintegration around him. If those who are involved in the punishment, or are even present at it, are 'coarsened and brutalised', then the author's very presence places him in danger of becoming like the officials whose indifference or even enjoyment so horrifies him, particularly as he has already integrated himself into the life of the colony in other ways, as indicated above. Only by absenting himself can he avoid being implicated in this process. For the sake of the objectivity of his report, he has to see and experience the punishment scene, but must avoid becoming an insider and being hardened to it. Therefore Chekhov (1978, p. 337) has to limit his vision in order to maintain his insight, and reassert his status as an outsider literally: 'I step outside'. In a world where the illiterate describe themselves as 'blind' (p. 71), the ability to see is associated here, not with the opposite values of civilisation or education, but with the danger of seeing too much, a loss of moral perspective and, paradoxically, a shift from enlightenment to darkness. ${ }^{24}$ Standing outside but still able to hear the sounds of the flogging, Chekhov (1978, p. 337) watches a passing convict, 'and his face, and even his walk, expressed horror'. In separating himself from the authorities he knows, he expresses his own horror by identifying with that of a convict he does not know, defamiliarising himself in order to access shared emotional and moral ground which allows him to participate in the prisoners' outsideness and enables greater insight in a single moment than all the work on his census achieved. To the extent that understanding is possible, it is associated not with proximity, facts and vision, but with distance, intuition and the other senses.

\footnotetext{
${ }^{23}$ As in the case of illness discussed in Badcock's essay, the brutality of punishment turns convicts into victims.

${ }^{24}$ This sense can be compared to Varlam Shalamov's insistence on the corrupting effect of Kolyma: 'There is a great deal there that man should not know, should not see, and if he has seen it, then it's better for him to die' (Shalamov 2004, p. 186).
} 
Chekhov identifies a large variety of crimes and vices among the convict and exile population, but the question of morality among the punished is one of the many areas in which he is unable to find definitive answers, which overall 'produces an extremely muddled and confused impression' (Chekhov 1978, p. 324). In contrast, there is no confusion over the officials' attitudes to corporal punishment, or the criminality and brutality of the guards; their capacity for depravity outstrips that of the convicts they are guarding and signifies a level of moral decay from which recovery seems impossible.

As Chekhov comes to these conclusions, it becomes clear that he views the question of punishment as being closely bound up with that of colonisation, and sees the degree of social and moral collapse on Sakhalin as indicative of the problematic nature of the process of colonisation through penal settlement. ${ }^{25}$ His frequent recourse to the word 'colony' and its derivatives - used over 170 times in the book-demonstrates that he perceives the island primarily in these terms, and was writing himself into a new generation of scholarly work on the subject in Russia (Breyfogle et al. 2007, p. 3). The mixed motives of the Russian penal system are responsible for many of the problems he defines, because:

when punishment, aside from its direct goals of retribution, instilling of fear, or correction, is set other aims, for example colonisation, then it must necessarily constantly adapt itself to the demands of the colony and make compromises. Prison is antagonistic to a colony, and the interests of the two are in inverse relation to each other. (Chekhov 1978, pp. 227-28) ${ }^{26}$

These compromises are presented as the cause of the indistinguishability he highlights so frequently; in the next paragraph he describes what actually happens irrespective of the legal situation:

[a]nd without any clauses or orders, but from necessity, because it is useful for the colony, outside the prison, in their own homes and in free-person's quarters, live all convict women without exception, as do many probationers and even those with life sentences, if they have a family or are good craftsmen, land surveyors, and dog drivers. (Chekhov 1978, p. 228)

The incompatible goals of the entire system, the inevitable absence of available structures to address this question, and the pragmatic approach to resolving the problems it causes, criminalise Sakhalin society as a whole, as officials disregard the law, criminality is only haphazardly punished, and non-criminals are treated effectively as equivalent to criminals. The result is that corruption, on both the personal and institutional levels, is normalised and becomes pervasive. ${ }^{27}$

Chekhov's analysis of life on Sakhalin suggests that colonisation through the creation of a penal settlement not only undermines the aims of the punishment-be they retribution or

\footnotetext{
${ }^{25}$ Chekhov's letter to A. S. Suvorin of 9 March 1890 indicates that his interest in Sakhalin lies in its use of convicts for colonisation (Chekhov 1976, p. 32). The essay by Sarah Badcock in this collection also deals with the question of colonisation through penal settlement. On the expansion of punitive colonisation in the Soviet era, see Viola (2007), Barenberg (2007) and Bell (2011, pp. 40-62).

${ }^{26}$ Gentes $(2008$, pp. 95,120$)$ shows that the practice of using exile to Siberia as a means of colonisation was established at an early stage and continued for much of the Imperial era. On colonial discourses and practices throughout Russian history, see Etkind (2011).

${ }^{27}$ See also Kropotkin (1887, pp. 154-69) on the connections between corruption and the economic and colonising uses of punishment, and Yadrintsev (1892, pp. 243-317) on the detrimental effects on colonial development of the presence of prisoners and exiles.
} 
reform — but also jeopardises the possibility of building a colony, primarily because the rule of difference ${ }^{28}$ is challenged by the development of a culture of sameness, which subverts the colonising status quo without introducing the equality that would resolve difference positively and engender reform, stability or growth. The colonising process and its distance from the Europeanised centre of Russian life theoretically defines a colonised other, but within the colony the population in practice becomes homogenised, as the convicts physically resemble the settlers, and the settlers and officials are morally indistinguishable from the convicts. Colonising in this way can only take the form of a levelling down and negation. With the loss of coloniser identity, the place of native islanders becomes uncertain; as the possibility of a social hierarchy has broken down and degrees of belonging are so ill-defined, no group can be identified definitively as other. Both insider and outsider status are undermined to create a sense of in-betweenness which paralyses all. The convicts' situation, as they are at once similar and dissimilar to the colonising authorities (as largely originating in European Russia and belonging to part of Russian society) and the colonised natives (as outcasts and beyond Russian society) is intensified by the establishment within colonisation through punishment of mutually exclusive goals of social inclusion and exclusion. Left in a limbo of both identity and social/legal position, the convicts' impasse comes to define the alienation of all the inhabitants, leaving society on Sakhalin unable to develop. ${ }^{29}$ Meanwhile, the colonisers are no longer within Russian society, but are instead infected by the outsideness they have created for the other, and occupy the same limbo. ${ }^{30}$ Thus, like Dostoevskii, for whom relationships within katorga exemplify the structure of Russian society and the divide between the narod and the élite, Chekhov's analysis of the penal question also reflects back on Russia, as his emphasis on the erasure of difference caused by the policy of colonisation implicates the Russian empire as a whole in the moral decay he describes.

\section{Conclusion}

In their relationships with and depictions of the ordinary convicts, all three authors prove unable to know their subjects, but their approaches to this problem construct different others which in turn shape their particular interpretations of the penal question. For Kennan, although one might expect Russia to emerge as the primary other, his text also works on a different level, with the convict as the other, an unseen presence, made more alien by their punishment than the Siberian landscape or its ethnic population. For Dostoevskii, as Goryanchikov fails to penetrate or comprehend the convict community in which he is placed, the peasantry becomes the other, and the division proves so unbridgeable that his narrator cannot live with the realisation of his failure. For Chekhov, unenlightened by his visit and surrounded by colonisers who have been dis-enlightened by living there, the other is Sakhalin, the exemplary penal colony, acting as a synecdoche for Siberia, Russia and its entire population.

If Kennan's work successfully highlights the problems of the penal system itself, then in the case of the two Russian authors, the form the other takes is significant because it is a

\footnotetext{
${ }^{28}$ See Cooper $(2005$, p. 23 ) on the politics of difference in colonial rule.

${ }^{29}$ Goryanchikov in the frame narrative of Notes from the House of the Dead occupies a similar in-between position, as outlined above.

${ }^{30}$ This can be seen as one of the effects of the process of self-colonisation described by Etkind (2011).
} 
dominant; the peasantry accounts for the largest proportion of the Russian population, and Siberia for the majority of Russia's land mass. Their texts thus speak to Russia's alienation from itself, originating in its social structure on the one hand and its position as a colonial power on the other. The result in Notes from the House of the Dead is a life that becomes untenable for the individual, and in Sakhalin Island a level of moral breakdown that destroys community wholesale. The convicts and their unknowability come to embody this alienation, and one could suggest that the tradition of writing about prison and exile, in which the works discussed here played such an important role, developed so powerfully in Russia in the nineteenth and twentieth centuries because it is in this subject that the fundamental political, social and moral problems Russia faces are crystallised.

\section{University College London}

\section{References}

Bagby, L. (1985) 'On Dostoevsky's Conversion: The Introduction to Notes from a Dead House', Symposium, $39,1$.

Bakhtin, M. (1984) Problems of Dostoevsky's Poetics (Minneapolis, MN, University of Minnesota Press).

Barenberg, A. (2007) From Prison Camp to Mining Town: The Gulag and Its Legacy in Vorkuta, PhD dissertation, University of Chicago.

Bell, W. (2011) The Gulag and Soviet Society in Western Siberia, 1929-1953, PhD dissertation, University of Toronto.

Breyfogle, N., Schrader, A. \& Sunderland, W. (2007) 'Russian Colonizations: An Introduction', in Breyfogle, N., Schrader, A. \& Sunderland, W. (eds) Peopling the Russian Periphery: Borderland Colonization in Eurasian History (London \& New York, Routledge).

Chekhov, A. (1976) Polnoe sobranie sochinenii i pisem v tridtsati tomakh. Pis'ma v dvenadtsati tomakh, IV: Yanvar' 1890-fevral' 1892 (Moscow, Nauka).

Chekhov, A. (1978) Polnoe sobranie sochinenii i pisem v tridtsati tomakh. Sochineniya v vosem'nadtsati tomakh, XIV-XV: Iz Sibiri; Ostrov Sakhalin (Moscow, Nauka).

Chekhov, A. (2007) Sakhalin Island (London, OneWorld Classics).

Cole, E. (1991) Towards a Poetics of Russian Prison Literature: Writings on Prison by Dostoevsky, Chekhov and Solzhenitsyn, PhD dissertation, Yale University.

Conrad, J. (1985) 'Chekhov as Social Observer: The Island of Sakhalin', in Clyman, T. (ed.) A Chekhov Companion (Westport, CT, Greenwood Press).

Cooper, F. (2005) Colonialism in Question: Theory, Knowledge, History (Berkeley \& Los Angeles, CA, University of California Press).

Doroshevich, V. (1903) Sakhalin (Katorga) (Moscow, Tipografiya Tovarishchestva I. D. Sytina).

Dostoevskii, F. (1972) Polnoe sobranie sochinenii v tridtsati tomakh, IV: Zapiski iz mertvogo doma (Moscow \& Leningrad, Nauka).

Dostoyevsky, F. (2004) The House of the Dead (London, Penguin).

Dwyer, A. (2012) 'Dostoevsky's Prison House of Nation(s): Genre Violence in Notes from the House of the Dead', The Russian Review, 71, 2.

Etkind, A. (2011) Internal Colonization: Russia's Imperial Experience (Cambridge, Polity Press).

Frank, J. (2010) Dostoevsky: A Writer in His Time (Princeton, NJ, Princeton University Press).

Gentes, A. (2008) Exile to Siberia, 1590-1822 (Basingstoke \& New York, MacMillan).

Hollingsworth, B. (1970) 'The Society of Friends of Russian Freedom: English Liberals and Russian Socialists, 1890-1917', Oxford Slavonic Papers, New Series, III.

Hundley, H. (2000) 'George Kennan and the Russian Empire: How America's Conscience Became an Enemy of Tsarism', Kennan Institute Occasional Papers, 277.

Jackson, R. (1981) The Art of Dostoevsky: Deliriums and Nocturnes (Princeton, NJ, Princeton University Press).

Jackson, R. (1993) Dialogues with Dostoevsky: The Overwhelming Questions (Stanford, CA, Stanford University Press).

Kennan, G. (1891a) Siberia and the Exile System, Vol. I (New York, The Century Company).

Kennan, G. (1891b) Siberia and the Exile System, Vol. II (New York, The Century Company).

Kropotkin, P. (1887) In Russian and French Prisons (London, Ward and Downey). 
Lincoln, W. (1994) The Conquest of a Continent: Siberia and the Russians (Ithaca, NY \& London, Cornell University Press).

Murav, H. (1991) 'Dostoevskii in Siberia: Remembering the Past', Slavic Review, 50, 4.

O'Connor, K. (2010) 'Reading “The Peasant Marei”" into the Text of Notes of the Dead House', unpublished paper delivered at the XIV International Dostoevsky Symposium, Naples.

Polakiewicz, L. (2001) 'Chekhov's The Island of Sakhalin and Dostoevsky's Notes from a Dead House as Penological Studies', Canadian-American Slavic Studies, 35, 4.

Popkin, C. (1992) 'Chekhov as Ethnographer: Epistemological Crisis on Sakhalin Island', Slavic Review, $51,1$.

Rosenshield, G. (1991) 'The Realization of the Collective Self: The Rebirth of Religious Autobiography in Dostoevskii's Zapiski iz Mertvogo Doma', Slavic Review, 50, 2.

Ruttenburg, N. (2008) Dostoevsky's Democracy (Princeton, NJ, Princeton University Press).

Ryfa, J. (1999) The Problem of Genre and the Quest for Justice in Chekhov's 'The Island of Sakhalin' (Lewiston, Edwin Mellen Press).

Shalamov, V. (2004) Sobranie sochinenii v shesti tomakh, I: Rasskazy 30-kh godov; Kolymskie rasskazy (Moscow, Terra).

Sunderland, W. (1996) 'Russians into Iakuts? "Going Native" and Problems of Russian National Identity in the Siberian North, 1870s-1914', Slavic Review, 55, 4.

Viola, L. (2007) The Unknown Gulag: The Lost World of Stalin's Special Settlements (New York, Oxford University Press).

Yadrintsev, N. (1892) Sibir' kak koloniya (St. Petersburg, Izdanie I. M. Siviryakova).

Young, S. (2010) 'Making and Using Concordances', 27 February, available at: http://sarahjyoung.com/site/ 2010/02/27/making-and-using-concordances/, accessed 8 November 2012. 